\title{
Centering Ukama Ethic (Relatedness) in the Covid-19 Pandemic 'New Normal' in African Higher Education
}

\author{
Joseph Pardon Hungwe ${ }^{1} \&$ Amasa. P. Ndofirepi ${ }^{2}$ \\ ${ }^{1}$ Post-doctoral Fellow, College of Education, University of South Africa, Pretoria, South Africa \\ ${ }^{2}$ Professor of Philosophy and History of Education, School of Education, Sol Plaatje University, Kimberly South \\ Africa \\ Correspondence: Amasa. P. Ndofirepi, Professor of Philosophy and History of Education, School of Education, Sol \\ Plaatje University, Kimberly South Africa.
}

Received: November 24, 2020

Accepted: April 28, 2021

Online Published: May 6, 2021

doi:10.5430/ijhe.v10n5p112

URL: https://doi.org/10.5430/ijhe.v10n5p112

\begin{abstract}
This conceptual article examines the ukama ethic concerning the Covid-19 pandemic-induced 'new normal' in African higher education. In so doing, we endeavor to appropriate ukama which is a communally oriented value system to militate against socially isolated individualism in Remote Learning and an Ethic of Care that combats social prejudices occasioned by the Covid-19 pandemic in African higher education. Our central argument is that Ukama ethic is contextually appropriate in the Covid-19 pandemic-induced 'new normal in African higher education. This article does two important things. Firstly, in light of the demands for local thought traditions in African higher education, it advances the social values of relatedness that constitute Ukama ethic to normatively underline the Remote Learning and Ethics of Care. In this regard, a question that is important to us is; if not now in the "new normal, then when can local thought traditions be fully incorporated into African higher education? Secondly, in the attempt to appropriate local thought traditions into African higher education, the article offers a critical reflection of Ukama. Despite its limitations, we conclude that the Ukama ethic is important in the Covid-19 pandemic induced 'new normal' in African higher education.
\end{abstract}

Keywords: Ukama ethic, remote learning, ethic of care, African higher education, Covid-19 new normal

\section{Introduction}

The Covid-19 pandemic has occasioned a need to integrate local thought traditions, which inform the epistemological and social values in higher education. In the context of Africa, higher education has been making sustained and consistent demands for local thought traditions as a countermeasure to Western hegemony (Ndlovu-Gatsheni, 2013, Masaka, 2018). The underlying presupposition is that local thought systems can appropriately and adequately respond to contextual social challenges obtaining in the African locality. Accordingly, this conceptual article utilises the Ukama ethic to interrogate the Covid-19 pandemic induced 'new normal' in African higher education. In so doing, we endeavor to appropriate Ukama which is a communally-oriented value system that can militate against socially isolated individualism in Remote Learning and an Ethic of Care that combats social prejudices occasioned by Covid-19 pandemic in the 'new normal in African higher education. Bearing in mind that the 'new normal' is multifaceted, we have chosen to focus on its two aspects namely, Remote Learning and Ethics of Care.

The focus on Remote Learning and Ethics of Care is rationalised by the realisation that the Covid-19 pandemic has had pronounced disruptive effects on the two, more than any other aspect of African higher education (Motala and Menon, 2020; Muftahu, 2020). In the same vein, it is noted that "the Covid-19 pandemic has demanded full migration to Remote Learning/ Teaching in which online would be expanded from its pre-Covid-19 pandemic use (Le Grange, 2020:2). Besides a few that offer distance education, most institutions of higher education in Africa have been or are offering contact education that requires students and staff to congregate at a geographical site for purposes of learning.

With the emphasis on Remote Learning, the Covid-19 pandemic 'new normal' poses a threat to the communally-oriented value in African higher education. We assert that Remote Learning poses social challenges to both students and staff since it may lead to socially isolated individualism. Essentially, isolated individualism contradicts the need for African higher education to produce graduates who can live and work with people of different races, ethnic and national groups. We are cognizant of the fact that in Africa, some universities have been offering 
Distance Education through Remote Learning. However, the most common form of delivery has been through contact face-to-face education. On the other hand, the imperative to interrogate the aspect of Ethics of Care is necessitated by the realization that the Covid-19 pandemic has occasioned social prejudices and stigmatisation of sectors of the higher education population (Dodds et al 2020). Because the origin and spread of the Covid-19 pandemic tend to be associated with certain countries, some higher education students are socially discriminated against based on their nationalities. Moreover, the Covid-19 pandemic has triggered a rise in instances of cases of xenophobia and racism within higher education.

In light of the imperative for African higher education to respond contextually to the 'new normal' that has been enforced by the Covid-19 pandemic, this article draws upon Ukama, which is a collectivist social scope of relatedness among the Shona people of Zimbabwe. Though this article is written from a Shona context, it is important to state that relatedness is cherished by most social groups in southern Africa and beyond through concepts such as Ubuntu. Nevertheless, there is a need for a critical assessment of local knowledge traditions and it is in line with this, that this article offers a critique to Ukama notion as a local thought tradition. This article, therefore, goes beyond a simple demand for the integration of local thought traditions into higher education. Our central argument is that Ukama as an ethical practice in Africa should conceptually be appropriated and deployed to 'normalise' the Covid-19 pandemic induced 'new norm' in African higher education. Over the past years, there have been agitated calls from the higher education sector for local thought traditions (Ikeke, 2015). It is therefore important that the 'new normal' should ideally draw from the local thought traditions such as the Ukama ethic in African higher education. In pursuit of this objective, the following question is crucial for us:

- What can the Ukama ethic offer to the appreciation of Remote Learning and the Ethics of Care as espoused in the Covid-19 pandemic-induced 'new norm' in African higher education?

In direct response to the above question, this article is divided into six interweaving subsections. In the first section, we sketch out the concept of Covid-19 pandemic-induced 'new normal' in higher education. In engaging the 'new normal, we seek to problematize and highlight the Covid-19 pandemic's disruption of the communally-oriented values in African higher education. As noted earlier, we do not cover all the aspects of 'new normal' but rather limit it to Remote Learning and the Ethics of Care perspectives. In the second section, we theorise the Ukama ethic of relatedness. The primary goal of this section is to expose the basic tenets that constitute Ukama. We are alive to the fact that as Shona's notion of relatedness, Ukama may not necessarily have the appeal in the broader African continent. Nevertheless, in light of advocating local knowledge traditions, this article advances Ukama ethic in the Covid-19 pandemic. In the third section, we appropriate the Ukama ethic to Remote Learning, while the fourth section deploys Ukama as a possible basis for Ethics of care. In line with the point of avoiding 'romanticising' thought traditions in Africa, the fifth section offers derives the tenet of common humanity encompassed in ukama. Finally, the sixth section gives a critical analytical exposition of on ukama. Moreover, critical reflection on Ukama is aimed at expanding it from a familial to a broad perspective so that it adequately caters for African higher education in the Covid-19 pandemic-induced 'new normal'. What then are the features of the Covid-19 pandemic-induced 'new normal'?

\section{The Covid-19 Pandemic Induced 'New Normal'}

While the 'new normal' notion is a multifaceted and multilayered term that describes the Covid-19 pandemic-enforced changes in higher education, in this article, we focus on remote learning and forms of ethical care that will be needed in the Covid-19 era. The Covid-19 pandemic has caused a profound impact on African higher education. Such profundity is evident through the enforced and rapid switch from contact to online remote learning as well as the ethics of care necessary against the Covid-19 pandemic (Mahona and Mkulu, 2020). The Covid-19 pandemic might be redefining our conceptualization of higher education. As the number of Covid-19 viral infections and deaths began to rise around March 2020, most governments in Africa closed down higher education institutions and primary schools. The traditional face-to-face contact teaching and learning was suspended, student residence closed down and students were informed to vacate the premises and go to their respective homes (Ali, 2020). While contact teaching and learning have relatively remained limited, there is a shift towards remote learning. Despite the non-availability or erratic internet services in most African countries, higher education is moving towards remote learning.

However, as we write this article, we somehow still believe that at some point, the pre-Covid- 19 pandemic 'old normal' settings in African higher education will return. There is an anticipation that the so-called new normal is only temporary and soon universities in Africa will be populated socially by university students and staff filling up lecturing, dining halls and libraries. Of course, such an image seems to be far-fetched from a reality that has made 
social distancing a commandment rather than a recommendation. Through the development of vaccination and other mitigating measures, there is hope that the new normal of online remote learning is but a passing phase. Moreover, the Covid-19 pandemic has given rise to the concept of 'working from home' which entails that both staff and students attend to academic assignments from their homes. The idea of home is rather generic thereby ignoring the suitability of some home settings for academic purposes. Equally so, the Covid-19 pandemic-induced 'new normal' compels a revisit to the idea of official working hours for both students and staff in African higher education. The idea of working from home as espoused in the 'new normal' begs the question on the re-evaluation of concepts such as team, group work and collegiality.

The 'new normal' has enforced African universities to migrate from Contact to Remote Learning. Under Remote Learning, higher education is provided through online digital platforms, a setup that consequently entails the replacement of physical on-campus lectures ( $\mathrm{Nel}$ and Marais, 2020). As a result, Remote Learning can be advantageous in the sense that it can be cheap because students do not incur travelling and accommodation expenses. Nonetheless, in the general context of Africa, there are numerous impediments to accessing online education in Africa. In summary, students face challenges such as having no access to a device including a laptop or smartphone, while there is instance there is either no network coverage or limited coverage, high cost of data, limited bandwidth, and living conditions not conducive to studying as well as hunger (Motala and Menon, 2020. In any case, the internet penetration in Africa is still lower in comparison to other continents (Mpungose, 2020). In this context, a crucial question to ask is: are the students having the necessary technological gadgets, experience, and discipline to use Remote Learning? Furthermore, the Covid-19 'new normal' may entrench elitism whereby students from economically and socially privileged classes may have more access to education than those from poor economic backgrounds.

From an ethical perspective, it is apparent that the Covid-19 pandemic has occasioned conspiracies and prejudices along with race, class, nationalities, and regionalism within higher education (Devi, 2020). With the rise in nationalism, border refortifications, scapegoating other nationals such as those from China and reference to Covid-19 as kung-fu virus (Guadagno, 2020), it can be logically stated that African, and higher education, in general, is 'socially immunised' from prejudices associated with Covid-19 pandemic. Subsequently, the need for contextually appropriate thought traditions that respond to the Covid-19 pandemic is important. Furthermore, the health mantra that 'everyone is positive until clinically tested otherwise' around which social distancing is founded upon requires 'new' ways of conceptualising social interactions, community relations, cosmopolitanism and all forms of citizenship. Equally, so the communally-orientated notions such as Ubuntu (unhu in Shona) upon which African higher education has been upholding (Shanyanana and Waghid, 2016) are being exposed to scrutiny by recommended Covid-19 pandemic etiquette. It is reasonable to assume that for the post-Covid-19 pandemic era, the retention of some values might be rather uncertain. It is also the case that some of the prejudices are influenced by the digital divide between the economically poor and rich as well as urban and rural students (Le Grange, 2020). Consequently, the need for Ethics of Care in which students' social interconnectedness is not compromised by prejudices is extremely important in the Covid-19 pandemic-induced 'new normal'. In this respect, the following subsection outlines the notion of the Ukama ethic.

\section{Theorising the Ukama Ethic}

Before delving into the theoretical underpinnings upon which Ukama ethic hinges upon, it is useful to place the issue under discussion within the broad scope of imperatives for local thought traditions in Africa. Ukama ethic finds resonance in the Ubuntu communitarian thought tradition that is common among Africans especially is a person in Southern Africa. Ukama is embodied in the Ubuntu maxim of umuntu ngumuntu ngabantu (a person through others) (Ndofirepi and Shanyanana, 2015). For a long time, African higher education has been crediting itself as the custodian of communally oriented notions such as Ubuntu (Horsthemke, 2004). It is within the broad scope of Ubuntu that Ukama ethic is conceptually located.

Ukama is a Shona notion of relatedness, social interconnectedness and bonding within the framework of family, extended family, totem-sharing and inter-marriage structure. As in other African contexts, the concept of family is not conceptually confined to a parochial perspective of biological ties of parents and children, but rather in a discursive sense to include extended family members. Furthermore, in its elastic terms, a family can be defined in terms of totems, surnames, clan names, village or district origin. In other words, ukama ethic for Waghid, Waghid and Waghid (2018), ukama is about relatedness that is espoused in communal norms (tsika) and expressed through solidarity. At the heart of ukama is the centrality of relatedness which is indispensable. Paradoxically, ukama ethic is a connection of relatives (hama) and exclusion of non-relatives (vatorwa). The aphorism chawa wana idya ne hama mutorwa ane 
hanganwa (what you achieve in life share with the relatives because if you share with strangers they can always abandon you in your hour of need) aptly captures the implicit exclusivity in ukama. Nevertheless, in cognisannce of the fact that non-relatives (vatorwa)'s stem root is torwa which means to incorporate, it can be claimed that $u k a m a$ can be extended and applies to common humanity. The Shona people claim that munhu wese ihama yako meaning everyone is your relative and therefore, must be treated with the ethics of care and respect.

In the further pursuit of theoretical clarity on ukama, Murove (2009) as well as Ndofirepi and Shanyanana (2016) attempt to derive the etymology of ukama from kama a Shona word for milking a cow. These scholars postulate that in the concept of ukama, there is dependence, as is the case with the milk provided by the cow sustains human life. However, such semantic etymology is rather problematic as it seems to suggest that ukama is a social network based upon dependence. In fact in Shona, milking is used pejoratively to denote abusive practices towards other people or animals. Rather, ukama designates relatedness, in other words, it is ascribed forms of relationships. Furthermore, ukama is underscored by inter-dependence instead of dependence; there is familial and communal mutual beneficiation. Though relatedness is couched in familial biological, ethnic, or village connections, their abundant room for incorporation and integration of new members.

From this foregoing theoretical exposition, it is apparent that the justification of employing in the African higher education, a sphere outside the family is drawn from three interlinked points. Firstly, ukama is not a closed ethnic tradition. On the contrary, ukama can be extended or expanded through social processes of incorporation such as marriage. Ukama facilitates the inter-tribal, international and racial marriages that have neutralised tribalism and racism tendencies in Zimbabwe. Secondly, the seeming exclusiveness connotations of ukama are not designed to entrench social divisions along family lines and enmity towards the 'non-relatives'. Rather, the seemingly exclusive connotation is tended towards protection, care, solidarity and compassion at the family level as the small unit in a village, district, or nation. In this way, ukama implies that the strengthening of relatedness ethos among higher education students capacitate them to relate to others as well. Among the Shona, the communal practices of solidarity espoused in ukama at a family level are supposed to cascade to all social structures. Moreover, as noted already, the assertion that everyone is your relative succinctly captures the encompassing nature of ukama. Thirdly, the centrality of relatedness in Ukama points to the essence of common humanity. While the expression of ukama might take different forms from family to higher education, what is critical is that relatedness remains a determining factor.

On the premise that relatedness is a central tenet of ukama, it is reasonable to argue that different higher educational institutions in Africa are communities of relations. While such relatedness may not be at an intimate level of biological connectedness, it cannot be entirely dismissed that students and staff of given universities share some common social experience. Moreover, students and staff derive some sense of belonging by the mere fact of studying or working at the institution. Perhaps, it is for that reason that upon graduation, students join the Alumni groups as a way of preserving the sense of belonging. It is for this reason that in the "new normal. It is important to state that though ukama is a familial bond, the family unit does not live outside the community. In precise terms, ukama ethic espouses collective responsibility, collaboration, interdependence, belonging, neighborliness and solidarity. In endeavoring to appropriate ukama ethic to African higher education, in the following two subsections we appropriate ukama in Remote Learning and Ethics of Care in the Covid-19 pandemic-induced 'new normal'.

\section{Ukama in Remote Learning: Facilitating Pedagogical Moments}

Given ukama ethic, we consider pedagogical moments as spaces in which the teaching and learning environment in the context of the Covid-19 pandemic is socially interactive, fraternal sharing and conversation that respect all forms of social diversity. From the onset of this section, a pertinent question is raised that "what does the blurring of the lines between the physical, digital and technological mean for social relationships and student learning? (Motala and Menon, 2020: 83). In response to this important question whose concern dovetails with the social connectedness of students studying in African higher education, we seek to centre ukama in Remote Learning. Remote learning which is sometimes interchangeable with Remote Instruction service in the Covid-19 pandemic is more oriented towards individual than communal learning. Pointedly, online teaching and learning is not an entirely new development since universities have experimented on blended learning, in which case there is a combination of contact tuition and online teaching and learning (Le Grange, 2020).

By implication, students can access learning material, study, communicate with the lecturer primarily via technological gadgets such as laptops and smartphones. Of course, in the scope of the Covid-19 pandemic requirement of social distancing, physical contact must be minimised as much as is possible. Yet, it is also true and logical that one of the cardinal goals for higher education is to produce graduates who can work and live in socially, culturally, racially and nationally diverse working environments. Moreover, as noted already in the preceding 
subsection, the Covid-19 pandemic gives urgency to collectivist norms like mutual care, compassion, and de-stigmatisation of other social groups. In conceptually appropriating the notion of ukama, the central question in this subsection is; how can the notion of ukama countervail excessive individualism that arises from online provisioning of higher education?

Additionally, in discussing Remote Learning, we make a distinction between physical and social distancing. Physical distancing does not necessarily entail social disconnectedness while social distancing presumes social disconnectedness (Unesco, 2020). While social distancing might be a pharmaceutical term for preventing the Covid-19 virus, physical distancing finds resonance with relatedness in ukama ethic. For instance, in Zimbabwe due to economic and political challenges, millions of Zimbabweans are located in the Diaspora. In that respect, though there is the physical distance, there is no social distancing. Physical distancing is mediated through technological gadgets such as phone, email, Skype and Facebook among other technological social media facilities. Under the ukama ethic, relatedness is cultivated through regular inter-personal communication.

Deriving from this exposition of ukama, the notion can be infused in the Remote Learning scope through pedagogical moments in which a lecturer can encourage learners to discuss and deeply engage on social issues that affect their education. In the context of many African countries, Remote Learning in which students learn and study from the home settings is often not ideal. Overcrowding, poor electricity, water supply and erratic internet services are some of the challenges associated with home settings for students in African higher education. In this respect, communicating on social issues that affect students and staff can act to reinforce relatedness and minimize isolated individualism. Ukama which is underlined by communal tenets such as relationality, relatedness and commonalities affirms the position that social problems shared are half-resolved (Ndofirepi and Shanyanana, 2015). By designation, such communication and sharing on social issues are tended towards avoiding a situation where institutions of higher education become mechanical. There is a danger if higher education institutions restrict themselves to mechanical disseminating knowledge through technological gadgets without necessarily addressing the social-relational needs of learners. This is important because during contact lectures before the advent of the Covid -19 pandemic, students used to immensely benefit from the extra-curricular social life of an institution of higher education.

By its very design, Remote Learning is an isolationist method of teaching and learning. Students are isolated from each other as they are confined to home settings. In this regard, there is the probability that both students and staff may lose multi-cultural skills, social networking, cosmopolitanism, and capacities to relate to those who are outside their family. Instead of developing relations with fellow students in the precincts of a university campus, students may end up getting fixated on technological gadgets. In deploying ukama notion of relatedness, Remote Learning should be conducted in a way that transcends individualism. The Shona adage rume rimwe hari kombi churu (no matter how physically strong one is, he/she needs assistance from others) is an ukama notion that can be applied to transcend isolated individualism that can be occasioned by Remote Learning. In our view, there is always a danger in an educational approach such as Remote Learning which can entrench academic competitiveness among students. Because in Remote Learning there is limited interaction of students, the concept of learning from each other may be highly compromised. Moreover, the ukama notion of relatedness will impress upon the students the necessity of collaborative learning. While the appropriation of ukama in Remote Learning is tended towards militating against social disconnectedness, loneliness and lack of social interactions, it is imperative to discuss the ethical implications of the Covid-19 pandemic-induced 'new normal'.

Despite the emergency of Remote Learning in higher education, society can continue to function through forms of social interactions that take into account the threat of the Covid-19 pandemic and possibly other future pandemics. Social distancing should not lead to social discrimination, stigmatisation and prejudices against some social groups. It is instructive that we state that in Remote learning, the technological skills that learners acquire can be used to enhance virtual relationships. For instance, students or learners should be phone from communal binding focus groups, which can be platforms to share their ideas, knowledge, impediments to learning and frustrations in the COvid-19 pandemic.

\section{Ukama in Ethics of Care: Building Pedagogical Community of Relations}

The Covid-19 pandemic has occasioned a context in which other people can be negatively stereotyped as careers and transmitters of the virus. Furthermore, the "Covid-19 pandemic has exacerbated social exclusion and the accompanying inequities. The lack of student access in the transition to Remote Learning has entrenched exclusion and created barriers to learning" (Motala and Menon, 2020). For instance, migrants often encounter stereotypes as a cohort that actively spread the Covid-19 virus (Guadagno, 2020). In times of crises such as the current Covid-19 pandemic, cases of racist, exclusionary and often violent practices, xenophobic conspiracies, cyberbullying and 
physical attacks tend to increase (Unesco 2020). Regrettably, socially vulnerable groups are used as scapegoats. It is logical to assume that in a continent that is constantly besieged with racism, tribalism and xenophobia, African higher education is likely to experience a resurgence of such social ills owing to the Covid-19 pandemic. Moreover, it is noted that "universities in Africa, as with their counterparts globally are required to contribute to the development of societies. Such advancements need to be underpinned by teaching and learning strategies that create well-educated, socially conscious citizens equipped with the knowledge, skills and attributes for rapidly changing era" (Motala and Menon, 2020: 82).

Because of the current rise in nationalism rhetoric, the Covid-19 pandemic excites stereotypes and social stigma. For example, referring to the Covid-19 as China virus is not only xenophobic but seems like making fun of the infected. On this basis, it is our persuasion that African higher education and higher education, in general, need the ukama ethics of care. In ukama it is not permissible is permitted to make a mockery of sick persons. Precisely, the aphorism that seka urema wafa (you should not denigrate the sick and frail) is a deterrent against stigmatising the sickly and physically disabled members of the community. Instead of inhospitality, ukama encourages compassion, care and support for the sick members. Because ukama regulates social behavior by prescribing norms and values, it is fair to argue that it can be employed to combat Covid-19 pandemic-associated stereotypes. We concur with the observation that African indigenous knowledge systems relate to all domains of life (Nel and Marais, 2020). Accordingly, ukama encompasses the social, political and economic vision of relatives and community members. In as much as this subsection has expounded on the theoretical underpinnings of ukama we are alive to the fact that this local thought tradition has its flaws. Moreover, in this article, we have alluded to the importance of exposing local thought traditions to critical appraisal.

Ukama ethic is underlined by relatedness that is expressed and experienced through Ethics of Care. Within the purview of care, there are commitments and obligations to care for one's siblings, parents and members of the extended family. For instance, the Western idea that once a person reaches the legal age of maturity, then parents or guardians are not be obliged to materially care for them is not common within the framework of ukama. In the same vein, learners are constantly reminded that once they complete, graduate and get gainfully employed, they are expected to take care of the other members of the immediate and extended family. Subsequently, attaining an academic qualification is both an individual and communal achievement that potentially benefits family members. Furthermore, Ethics of Care in ukama obliges learners to assist one another in their academic assignments. You do not learn for yourself but learn for others through others. From a common humanity perspective, the aphorism that muenzi haapedizi dura (giving a visitor some food does not exhaust one's pantry storage reserves) aptly captures the elasticity of ukama to interconnect with humanity. It is instructive that we point out that ukama common in southern Africa. In this way, ukama is a concrete application of other ethics within southern Africa such as Ubuntu.

In fact, in ukama though a person may not be a biological relative, every person is supposed to be accorded human respect. Ethics of care implies the norms, injunctions and values that guide members on hospitality towards the sick. In centering the ukama notion of ethics of care in the Covid-19 pandemic, higher education institutions will enhance practices and values of hospitality, compassion, empathy, tolerance and respect for social diversity within the student and staff composition. It is stated ukama is underpinned by relational values that encourages members to share during both times of abundance and scarcity (Ndofirepi and Shanyanana-Amaambo, 2015). These outlined tenets of ukama are essential in theCovid-19 pandemic 'new normal' in African higher education. A community of students, learners and staff that takes care of each other is critical especially in a pandemic that demands social distancing. At a practical level, students can be introduced to practices of concern to one another, the kind of concern that accounts for common humanity as depicted in the following section.

\section{Ukama and Common Humanity}

Covid-19 pandemic has affirmed the aspect of common humanity. It has become clear that the virus behind this pandemic cannot be stopped by national borders, race, age, religion and other social categories. To that end, in this section, ukama ethic is appropriated to common humanity within higher education in Africa. This appropriation is foregrounded by the acknowledgment that Africa is a highly diversified continent in terms of social composition along with race, ethnicity, language, religion and other social categories. Moreover, even before the emergence of the Covid-19 pandemic, there have been intermittent violent social conflicts across many African countries. Accordingly, there is a dimension of common humanity in ukama ethic which can be deployed in the Covid-19 pandemic 'new normal' in African higher education. As noted already, ukama affirms that everyone is your relative. There are possibilities of becoming a relative through harmonious coexistence that can be expressed through compassion, care and support. For instance, those who are not related through blood connections "can adopt terms like sekuru 
(grandfather/uncle), muzukuru (cousin/nephew) towards each other to express friendly relationship from both the father and mother's side (Mhaka, 2010). Though Ukama ethic's relatedness is fundamentally premised on shared commonality bonds along with blood relations, marriage, clan and totems, non-relatives, and people of different ethnic, racial, nationalities and other social categorisation are not deliberately discriminated against. It is instructive that we state that in ukama there is a binary of hama (relative) and vatorwa (non-relative/outsider). In ukama ethic, vatorwa's root stem is tora, which means to take, acquire or secure. In other words, there are cultural ways of assimilating people who may not necessarily be blood relatives. There are possibilities of becoming a relative, thus incorporation or assimilation is embedded in ukama ethic. Ukama is a common connector of sharing and uniting all humanity. In ukama framework, an individual is seen in the light of his or her family. In the ukama ethic, humanity is inseparable. A family both nucleus and extended as well as clan, the village of origin is bound by tsika (normative/ prescribed practices and values) in the form of a shared cultural worldview, language

Exclusive relatedness along blood relations does not necessarily imply that one has to be harmful towards non-relatives. In ukama there are conduits to coexistence and tolerance towards non-relatives. Perhaps, it is for this reason that during the period when foreign nationals from neighboring countries such as Malawi, Zambia and Mozambique immigrating into Zimbabwe, there were no reported cases of violent attacks towards foreign nationals. Intermarriage between foreigners and Zimbabweans was common. Henceforth, in ukama ethic, the tenet of common humanity can adequately address social discrimination practices such as xenophobia and racism, which has been triggered by the Covid-19 pandemic.

\section{A Critical Appraisal on Ukama}

This subsection aims to give a critical appraisal of the notion of ukama as local thought traditions that have the potency of being fully incorporated into African higher education. We must state the fact that relatedness is not a uniquely Shona culture as espoused in the ukama ethic. In all cultures, relatedness is expressed in different forms. In specific terms, ukama endows obligations and commitment towards relatedness. The reason for doing a critical appraisal of ukama notion is to recalibrate its shortcomings so that it is appropriated conceptually within African higher education. We observe that all knowledge systems and ethical beliefs have inherent limitations. In our view, there are four limitations that ukama has to overcome as part of the integration process into formal higher education. In this case, a critical appraisal endeavors to recalibrate it so that it is appropriated in African higher education. Local knowledge systems must be reflected critically so that their demerits can be alleviated.

Firstly, ukama is specifically a Shona practice of relatedness and appearing to suggest that it should be imposed within African higher education can be detrimental. We are cognisant of the fact that in Africa, there are social challenges such as tribalism, xenophobia and racism. Basing on the presence of such social ills, some tribes or races may resist ukama not because of its flaws, but because it is an import from a Shona tribe. However, as academics with vast experience in African higher education, we are convinced that the centering of a local thought tradition such as ukama may facilitate scholarly deliberation on the integration of local thought systems. Ideally, such scholarly deliberation will be informed by merits rather than the tribal or racial connotations of the local thought system. Secondly, though we have already dealt with the exclusive connotations of ukama in the above sections, there is a need to emphasize that the essentialisation of biological relatedness can be problematic in a socially diverse institution like the higher education sector. In this respect, ukama is a closed system that borders around ethnicity and linguistic demarcations. Therefore, as a thought system in higher education, there is a need that relatedness is stretched to socially accommodate diversity. In our view, the expansion of ukama to accommodate social diversity is possible considering that it is a thought tradition that is constantly evolving. For instance, people who live in the same neighbourhood or village tend to develop recognisable relatedness

Thirdly, ukama is highly hierarchical. There is unquestionable loyalty to the elders, authority and religious figures who are assumed to be the custodians of family or totem practices, wisdom and guidance. In the ukama notion, elders are never wrong and young people are perceived as persons who need guidance. The unexamined application of the notion of ukama might mean that students will not be able to challenge higher education authorities and lecturers. In analysis, it is apparent that the unquestionable loyalty to hierarchy, the received 'wisdom' might infringe upon academic pursuits such as Critical Thinking.

Fourthly, ukama is prescriptive rather than deliberative. A value tradition is prescriptive when members are compelled to observe the stated values. The sage wisdom which is founded in ukama is progressively passed on from one generation to the other. On the other hand, higher education is by its very design conduit of deliberative practices and ethos. In higher education, the consensus is not reached through the generational imparting of practices and values but rather is sought through critical reflection. It is important to state that the limitations raised in this section do not 
warrant the dismissal of ukama. On the contrary, ukama can play a pivotal role in minimising the isolated individualism, social prejudices and stigmatization associated with the Covid-19 pandemic-induced 'new normal' embedded in Remote learning and Ethics of Care in African higher education.

\section{Conclusion}

Arguments have been advanced that the obtaining models and modes of knowledge systems and educational philosophies are more influenced by Western canons. One of the emerging 'truths' from the decolonization of higher education in Africa is that every human society is endowed with a valuable knowledge system. Such a valuable knowledge system is supposed to be applied in response to the immediate social, economic, political and health challenges. In cognizance of the fact that a pandemic such as Covid-19's course is determined by the contextual response, this article draws upon Ukama ideals as a response to Covid-19. This article observed how the disruptive tendencies of the Covid-19 pandemic have ravaged higher education teaching and learning and thus recommends the incorporation of local knowledge practices and ethical values including Ukamain order to ameliorate the current challenges ushered by the incursion of the virus in institutions of higher learning.

\section{References}

Ali, W. (2020). Online and Remote Learning in higher education institutes: A necessity in light of COVID-19 pandemic. Higher Education Studies, 10(3), 16-25. https://doi.org/10.5539/hes.v10n3p16

Devi, G. (2020). America's international students are facing deportation: This is disaster, The Guardian, https://www.theguardian.com/commentisfree/2020/jul/09/us-colleges-international-students-ice-deportation (Accessed by $11^{\text {th }}$ November 2020).

Dodds, K., Broto, V. C., Detterbeck, K., Jones, M., Mamadouh, V., Ramutsindela, M., Varsanyi, M., Wachsmith, D., \& Woon, C. Y. (2020). Territory, Politics, Governance, 8(3), 289-298. https://doi.org/10.1080/21622671.2020.1771022

Guadagno, L. (2020). Migrants and the Covid-19 pandemic: An initial analysis. Migration Research Series (60). International Organization for Migration. https://publications.iom.int/books/mrs-no-60-migrants-and-covid-19-pandemic-initial-analysis

Ikeke, M. O. (2015). Ukama ethic as an African Environmental ethics. International Journal of Theology and Reformed Tradition, (7), 202-211.

Keeling, R. P. (2014). An Ethics of Care in higher education: Well-being and learning. Journal of College Character, 15(3), 141- 158. https://doi.org/10.1515/jcc-2014-0018

Le Grange, L. (2020). Could the Covid-19 pandemic accelerate the Uberfication of the university? South African Journal of Higher Education, 34(4), 1-10. https://doi.org/10.20853/34-4-4071

Mapara, J. (2009). Indigenous knowledge systems in Zimbabwe: Juxtaposing postcolonial theory. The Journal of Pan African Studies, 3(1), 139-155.

Masaka, D. (2018). The prospects of ending epistemicide in Africa: Some thoughts. Journal of Black Studies, 49(3), 284-301. https://doi.org/10.1177/0021934717753731

Mhaka, V. (2010). "Becoming a Christ for your neighbor": Exploring Lutheran notion of neighborliness in light of ukama and Ubuntu in the Zimbabwean Lutheran church. Unpublished Masters in Theology (Theology and Development). University of Kwazulu-Natal,

Mpungose, C. B. (2020). Emergent transition from Face to Face to Online learning in a South African university in the context of Coronavirus. Humanities and Social Sciences Communication, (7), 1-9. https://doi.org/10.1057/s41599-020-00603-x

Muftahu, M. (2020). Higher education and Covid-19 pandemic: Matters arising and the challenges of sustaining Academic Programs in developing African universities. International Journal of Educational Research and Review, 5(4), 417-423. https://doi.org/10.24331/ijere.776470

Ndlovu, M. (2014). Why indigenous knowledges in the $21^{\text {st }}$ century? A decolonial turn. Yesterday \& Today, (1), 84-98.

Ndlovu-Gatsheni, S. J. (2013). The dynamics of epistemological decolonisation in the $21^{\text {st }}$ century: Towards Epistemic freedom. Strategic Review of Southern Africa, 40(1), 16-45. 
Ndofirepi, A. P., \& Gwaravanda, E. T. (2017). Epistemic (in)justice in African universities: a perspective of politics of knowledge. Educational Review, 71(5), 21-43. https://doi.org/10.1080/00131911.2018.1459477

Ndofirepi, A., \& Shanyanana-Amaambo, R. (2015). Rethinking Ukama philosophy in the context of 'Philosophy for Children' in Africa. Research Papers in Educaion, 1-14. https://doi.org/10.1080/02671522.2015.1073773

Nel, C., \& Marais, E. (2020). Preservice teachers use of WhatsApp to explain subject content to school children during Covid-19 pandemic. Special Issue: Responding to Covid-19: Exploration and Expansion of Good Practice of Work-integrated Learning, 21(5), 629-641.

Unesco. (2020). The social cultural implications of COVID-19. Unesco. https://en.unesco.org/news/socio-cultural-implications-covid-19. (Accessed 4th November 2020).

Shanyanana, R, N., \& Waghid, Y. (2020). Reconceptualising Ubuntu as inclusion in African Higher education: Towards equalization of voice. Knowledge Cultures, 4(4), 104-120.

Waghid, Y., Waghid, F., \& Waghid, Z. (2018). What happens when you put African philosophies at the centre of learning. The

Conversation. https://theconversation.com/what-happens-when-you-put-african-philosophies-at-the-centre-of-learning-95465 (Accessed $16^{\text {th }}$ October 2020).

\section{Copyrights}

Copyright for this article is retained by the author(s), with first publication rights granted to the journal.

This is an open-access article distributed under the terms and conditions of the Creative Commons Attribution license (http://creativecommons.org/licenses/by/4.0/). 